\title{
The Effectiveness of Science Module Smp / MTS to Train Critical Thinking Skills
}

\author{
Ahmad Misradi Surya $^{1 *}$, Muhammad Zaini ${ }^{2}$, Supramono ${ }^{3}$ \\ ${ }^{1}$ Master Program of Science Teaching, Lambung Mangkurat University, Indonesia \\ ${ }^{2}$ Department of Biology Education, Faculty of Teacher Training and Education, Lambung Mangkurat University, Banjarmasin, Indonesia \\ ${ }^{3}$ Department of Biology Education, Faculty of Teacher Training and Education, Palangkaraya University, Indonesia
}

DOI: 10.36348/JAEP.2019.v03i10.002 | Received: 26.09.2019| Accepted: 03.10.2019| Published: 14.10 .2019

*Corresponding author: Ahmad Misradi Surya

Abstract

This research aims to evaluate the effectiveness of the use of natural science module SMP/MTs to train critical thinking skills. The research subject of students grades VIII MTs Muhammadiyah 3 Al-Furqan Banjarmasin. The experiment was conducted in the academic year 2018/2019. Data on the effectiveness of the modules include the cognitive learning, critical thinking skills, attitude, character, social attitudes, and responses of students. Data were collected through questionnaires and observations and analyzed descriptively. The results showed module IPA developed relatively effective based on 1) the cognitive learning of students has exceeded the classical completeness, 2) critical thinking skills of students categorized as good, 3) the attitude of the character of the students are diligent and cautious good average, 4 ) social attitudes of students working together and express good average, and 5) the average response has been good.

Keywords: Module, critical thinking skills, effectiveness.

Copyright @ 2019: This is an open-access article distributed under the terms of the Creative Commons Attribution license which permits unrestricted use, distribution, and reproduction in any medium for non-commercial use (NonCommercial, or CC-BY-NC) provided the original author and sources are credited.

\section{INTRODUCTION}

Learners in Indonesia still have poor thinking skills, especially in the implementation of science [1], Overall scientific literacy learners Indonesia based on data from PISA 2015 is relatively low, which is ranked 62 out of 69 countries evaluated [1]. The poor thinking ability has not shown an increase over time.

Critical thinking skills are part of the highlevel thinking skills. Filsaime [2] describes the critical thinking is a process that emphasizes think logically and rationally. Critical thinking skills can be acquired through practical activities in the learning process (classroom activity).

The learning process in schools usually uses textbooks from a particular publisher. It is a constraint, of course, is the discrepancy between the existing teaching materials to the learning objectives following the syllabus. Besides teaching materials used have not loaded critical thinking skills as the main bill. If this is allowed, then the critical thinking skills of Indonesian children remain underdeveloped. Therefore it is necessary for the innovation-oriented learning process. One way that can be done to improve the learning process is a way to improve learning resources. Learning resources (books students) have constraints, whether the amount is very limited, as well as distribution.

Expectations by developing modules science teaching is the students can learn from the experience of real-life, happy, learning with excitement, students actively and critically, fun, and sharing with friends so that learners will be plenty of opportunities to learn independently and to reduce dependence on the presence of teachers so that students will find it easy to learn each competency to be mastered. So that the ultimate goal is the development of this science module to train the critical thinking skills of learners can be achieved.

Product development of a prototype module, this is done through the procedural steps to improve the product. Each step is a microcycle that ends with the revision [3]. So that the resulting module quality, the necessary measures through the development of expert review, one to one evaluation, small group, and field test [4]. Through this way will obtain a valid module, practical, and effective.

\section{METHODS}

The model used is a model of development that Tessmer formative evaluation and use of research 
planning and development. This research approach emphasizes the formative stages of evaluation by Tessmer [4], which includes expert reviews, one to one evaluation, small group and field test.

The actual effectiveness of data obtained from the student's cognitive learning, critical thinking skills of students, the characterless attitude of learners, social attitudes of learners, and the response of students in the field test. Data collection techniques in the development of this module obtained through evaluation sheets cognitive achievement of learners, learner's critical thinking skills, character attitude of learners, social attitudes of learners, and the response of students in the small group test. Similarly, the actual effectiveness obtained through evaluation sheets cognitive assessment of learning outcomes learners, critical thinking skills of learners, the characterless attitude of learners, social attitudes of learners, and the response of students in the field test.

The actual effectiveness of data analysis techniques was analyzed using a rubric. Steps as follows; a) Data cognitive learning outcomes of learners using a score of $10-100$; b) the data critical thinking skills of learners carry out practical activities in groups then match the types of critical thinking skills (formulate problems, make hypotheses, designing experiments / observations, collecting data, analyzing data, drawing conclusions, and presented the results of the experiment). The results associated with the category of Very Good (4), good $(3 \leq 4)$, good enough $(2 \leq 3)$, poor $(1 \leq 2)$. (Adapted from Nur, 2013); c) the data in character and attitude of social attitudes based on an assessment rubric with excellent category (4), good $(3 \leq 4)$, good enough $(2 \leq 3)$, poor $(1 \leq 2)$ (Adapted from Nur, 2013) [5]; d) the response data learners through a questionnaire, obtained from the checklist in the "yes" or "no". Furthermore, answer "yes" summed divided by the number of indicators expressed in percent and is categorized as very good (85.01 to $100.00 \%)$, Pretty Good (70.01 to $85.00 \%)$, less good (from 50.01 to $70,00 \%$ ), and not good (10.00- 50.00\%).

\section{RESULTS AND DISCUSSION Effectiveness Hope}

The effectiveness of expectations based on a) the cognitive learning, b) critical thinking skills, c) the attitude of the character, d) social attitudes, e) test the response of students in small groups.

\section{Student Learning Outcomes}

Table-1: Results of Cognitive Learning in Small Groups

Table-1: Results of Cognitive Learning in Small Groups
\begin{tabular}{|l|l|l|l|l|l|l|l|}
\hline \multirow{2}{*}{ Nr. } & \multirow{2}{*}{ Student Initials } & \multicolumn{6}{|c|}{ Cognitive On Module } \\
\cline { 3 - 9 } & & $\mathbf{1}$ & $\mathbf{2}$ & $\mathbf{3}$ & $\mathbf{4}$ & $\mathbf{5}$ & $\mathbf{6}$ \\
\hline 1 & A & 100 & 100 & 100 & 100 & 100 & 100 \\
\hline 2 & CA & 90 & 80 & 100 & 90 & 100 & 90 \\
\hline 3 & GUA & 70 & 80 & 80 & 80 & 90 & 90 \\
\hline 4 & L & 70 & 80 & 80 & 80 & 90 & 90 \\
\hline 5 & MFA & 80 & 80 & 80 & 80 & 70 & 80 \\
\hline 6 & SDF & 70 & 80 & 80 & 90 & 80 & 90 \\
\hline Classical completeness (\%) & 100 & 100 & 100 & 100 & 100 & 100 \\
\hline
\end{tabular}

$\mathrm{KKM}=$ Minimum Completeness Criteria (minimum criteria of mastery learning)

$\mathrm{KKM}=70$, Classical Completeness $80 \%$

Based on Table-1 all students have been completed $100 \%$ and have exceeded the minimum of $80 \%$ classical completeness.

\section{Critical Thinking Skills}

The results of the student's critical thinking skills in small groups are presented in Table-2.

Table-2: The results of the test of critical thinking skills small groups

\begin{tabular}{|l|l|l|l|}
\hline Nr. & Critical Thinking Skills & Average & Category \\
\hline 1. & formulate the problem & 3.00 & Good \\
\hline 2. & formulate hypotheses & 3.00 & Good \\
\hline 3. & Designing Experiments/observations & 3.50 & Good \\
\hline 4. & Collecting data & 3.42 & Good \\
\hline 5. & analyzing the data & 3.00 & Good \\
\hline 6. & drawing conclusions & 3.17 & Good \\
\hline
\end{tabular}

Categories:

$$
\begin{array}{ll}
4=\text { Very good } & 3-\leq 4=\text { Good } \\
2-\leq 3=\text { Less good } & 1-\leq 2=\text { Not good }
\end{array}
$$

Table-2 shows that the critical thinking skills of students most of the indicators are good. 
Character Attitude of Students (Diligent and Be careful)

Table-3: Results, the assessment of character in a small group test

\begin{tabular}{|l|l|l|l|l|l|}
\hline \multirow{2}{*}{ Nr. } & Student Initials & \multicolumn{2}{|l|}{ Diligent } & Carefulness \\
\cline { 3 - 6 } & & Score & Category & Score & Category \\
\hline 1 & A & 3.62 & Good & 3.88 & Good \\
\hline 2 & CA & 3.75 & Good & 3.50 & Good \\
\hline 3 & GUA & 3.50 & Good & 3.62 & Good \\
\hline 4 & L & 3.12 & Good & 3.25 & Good \\
\hline 5 & MFA & 3.50 & Good & 3.38 & Good \\
\hline 6 & SDF & 3.38 & Good & 3.50 & Good \\
\hline
\end{tabular}

Based on Table-3 attitude characterized the small group test all students both in the attitude of diligent and cautious.

Social Attitudes of Students (cooperation and express opinion)

Table-4: The results of the assessment of social attitudes in a small group test

\begin{tabular}{|l|l|l|l|l|l|}
\hline \multirow{2}{*}{ Nr. } & \multirow{2}{*}{ Name } & \multicolumn{2}{l|}{ Cooperation } & \multicolumn{2}{l|}{ Expression } \\
\cline { 3 - 6 } & & Score & Category & Score & Category \\
\hline 1 & A & 3.62 & Good & 3.88 & Good \\
\hline 2 & CA & 3.25 & Good & 3.38 & Good \\
\hline 3 & GUA & 3.62 & Good & 3.38 & Good \\
\hline 4 & L & 3.50 & Good & 3.25 & Good \\
\hline 5 & MFA & 3.88 & Good & 3.88 & Good \\
\hline 6 & SDF & 3.38 & Good & 3.50 & Good \\
\hline
\end{tabular}

Based on Table-4 social attitudes in small group test all learners have good while doing cooperation and expressed opinions during group discussions.

\section{Response of Students}

Response Students in small group test are presented in Table-5.

Table-5: Response of Students of the modules on a small group of test

\begin{tabular}{|l|l|l|l|l|}
\hline No. & Statement & $\begin{array}{l}\text { The Number } \\
\text { of Students }\end{array}$ & \% & Category \\
\hline 1 & I am very pleased to learn the lab & 6 & 100 & Very good \\
\hline 2 & I can understand very well the activities in the module & 6 & 100 & Very good \\
\hline 3 & $\begin{array}{l}\text { I came to understand all the material in the modules dealing with } \\
\text { everyday life }\end{array}$ & 6 & 100 & Very good \\
\hline 4 & I could design an experiment & 5 & 83.33 & Good \\
\hline 5 & I've been able to process the data after performing experiments & 6 & 100 & Very good \\
\hline
\end{tabular}

Description categories:

$$
\begin{aligned}
& 85-<100 \%=\text { very good } \quad 50-<70 \%=\text { less } \\
& \text { good } \\
& 70-<85 \%=\text { Good } \quad 10-<50 \%=\text { not } \\
& \text { good } \\
& \text { Adapted from Nur (2013) [5] }
\end{aligned}
$$

Most of the responses of students in a small group of states that IPA development module is very good and interesting to learn.

\section{Actual Effectiveness}

The effectiveness is obtained by a) the cognitive learning, b) critical thinking skills, c) the attitude of the character, d) social attitudes, e) the response of students in the field test.

\begin{tabular}{|c|c|c|c|c|c|}
\hline Number of students & Module & KKM & Master & Not Yet Mastered & Classical Completeness (\%) \\
\hline 32 & 1 & \multirow[t]{6}{*}{70} & 29 & 3 & 90.6 \\
\hline 32 & 2 & & 31 & 1 & 96.9 \\
\hline 32 & 3 & & 30 & 2 & 93.8 \\
\hline 32 & 4 & & 30 & 2 & 93.8 \\
\hline 32 & 5 & & 29 & 3 & 90.6 \\
\hline 32 & 6 & & 30 & 2 & 93.8 \\
\hline
\end{tabular}

\section{Learning Outcomes of Students (Cognitive)}

Student learning outcomes in the group can field test are presented in Table-6.

Table-6: Results of Field Test of Cognitive Students

$\mathrm{KKM}=$ Minimum Completeness Criteria (minimum criteria of mastery learning)

$\mathrm{KKM}=70$, Complete Classical $80 \%$ 
Ahmad Misradi Surya et al; J Adv Educ Philos, Oct 2019; 3(10): 350-356

From the data obtained the learning outcomes of the subject of six modules in the classical declared complete because it exceeds the value of classical completeness $80 \%$, but some students have not completed because the value is less than the KKM is 70.

Critical Thinking Skills test group field

Critical thinking skills groups are presented in Table-7.

Table-7: Critical Thinking Skills Group

\begin{tabular}{|l|l|l|l|}
\hline No. & Critical thinking skills & Average & Category \\
\hline 1. & formulate the problem & 3.14 & Good \\
\hline 2. & formulate hypotheses & 3.19 & Good \\
\hline 3. & Designing Experiments/observations & 3.33 & Good \\
\hline 4. & Collecting data & 3.33 & Good \\
\hline 5. & analyzing the data & 3.29 & Good \\
\hline 6. & drawing conclusions & 3.29 & Good \\
\hline
\end{tabular}

Description categories:

$$
\begin{array}{ll}
\text { Very good (4) } & \text { Good }(3-<4) \\
\text { Less good }(2-<3) & \text { Not good }(1-<2) \\
\text { (Adapted from Nur, 2013) [5] } &
\end{array}
$$

Results from the data in Table-7 shows that the critical thinking skills of students are good, although there are no students who obtained a very good category. The highest average value of each category was 3.33 with a good category and the lowest rate was 3.14 also with both categories.

Character Attitude of Students (Diligent and Be Careful)

Table-8: The results of the test, the assessment of character Courses

\begin{tabular}{|l|l|l|l|l|l|}
\hline \multirow{2}{*}{ No. } & Initials Students & \multicolumn{2}{|l|}{ Diligent } & \multicolumn{2}{|l|}{ Carefulness } \\
\cline { 2 - 6 } & & Score & Category & Score & Category \\
\hline 1 & APH & 3.38 & Good & 3.62 & Good \\
\hline 2 & AYR & 3.75 & Good & 3.88 & Good \\
\hline 3 & AZA & 3.50 & Good & 3.75 & Good \\
\hline 4 & AI & 3.50 & Good & 3.62 & Good \\
\hline 5 & A A & 3.88 & Good & 3.88 & Good \\
\hline 6 & CZA & 3.75 & Good & 3.75 & Good \\
\hline 7 & CNRP & 3.50 & Good & 3.62 & Good \\
\hline 8 & HK & 3.88 & Good & 3.62 & Good \\
\hline 9 & KNS & 4.00 & Very good & 3.38 & Good \\
\hline 10 & LSA & 3.62 & Good & 3.88 & Good \\
\hline 11 & LA & 3.38 & Good & 3.38 & Good \\
\hline 12 & MAP & 3.12 & Good & 3.12 & Good \\
\hline 13 & MAR & 3.62 & Good & 3.62 & Good \\
\hline 14 & MKNZ & 3.62 & Good & 3.62 & Good \\
\hline 15 & MSP & 3.38 & Good & 3.38 & Good \\
\hline 16 & MWH & 3.88 & Good & 3.88 & Good \\
\hline 17 & MZE & 3.75 & Good & 3.75 & Good \\
\hline 18 & MZH & 3.75 & Good & 3.75 & Good \\
\hline 19 & MMP & 3.88 & Good & 3.88 & Good \\
\hline 20 & M & 3.88 & Good & 3.88 & Good \\
\hline 21. & MH & 3.75 & Good & 3.38 & Good \\
\hline 22. & MR & 3.88 & Good & 3.75 & Good \\
\hline 23. & NN & 3.38 & Good & 3.50 & Good \\
\hline 24. & NH & 3.62 & Good & 3.50 & Good \\
\hline 25. & NFH & 3.88 & Good & 3.88 & Good \\
\hline 26. & NU & 3.75 & Good & 3.75 & Good \\
\hline 27. & NNA & 3.88 & Good & 3.50 & Good \\
\hline 28. & NH & 3.75 & Good & 3.88 & Good \\
\hline 29. & NSB & 3.88 & Good & 3.75 & Good \\
\hline 30. & RS & & & 3.62 & Good \\
\hline 31. & SD & SR & Good & Good \\
\hline 32. & SR & \\
\hline & & Ad & from \\
\hline
\end{tabular}

Description categories:

$$
\begin{aligned}
& \text { Very } \operatorname{good}(4) \\
& \text { Less } \operatorname{good}(2-\leq 3) \\
& \operatorname{good}(1-\leq 2) .
\end{aligned}
$$

Good $(3-\leq 4)$

Not
(Adapted from Nur, 2013) [5]

Based on Table- 8 the attitude of the character (diligent and careful) at an average of field testing has 
Ahmad Misradi Surya et al; J Adv Educ Philos, Oct 2019; 3(10): 350-356

been good students. There is only one student who obtained a very good category. The highest average value of each learner is 4.00 with very good categories and the lowest value was 3.12 in both categories.
Social Attitudes of Students (Cooperate and Expression)

Table-9: Assessment of social attitudes in the field test

\begin{tabular}{|l|l|l|l|l|l|}
\hline No. & Initials Students & \multicolumn{2}{|c|}{ Cooperate } & \multicolumn{2}{|c|}{ Expression } \\
\cline { 3 - 6 } & & Score & Category & Score & Category \\
\hline 1 & APH & 3.62 & Good & 3.38 & Good \\
\hline 2 & AYR & 3.62 & Good & 3.12 & Good \\
\hline 3 & AZA & 3.38 & Good & 3.62 & Good \\
\hline 4 & AI & 3.62 & Good & 3.62 & Good \\
\hline 5 & A A & 3.38 & Good & 3.88 & Good \\
\hline 6 & CZA & 3.12 & Good & 3.88 & Good \\
\hline 7 & CNRP & 3.62 & Good & 3.75 & Good \\
\hline 8 & HK & 3.62 & Good & 3.75 & Good \\
\hline 9 & KNS & 3.38 & Good & 3.88 & Good \\
\hline 10 & LSA & 3.88 & Good & 3.88 & Good \\
\hline 11 & LA & 3.75 & Good & 3.38 & Good \\
\hline 12 & MAP & 3.75 & Good & 3.12 & Good \\
\hline 13 & MAR & 3.88 & Good & 3.62 & Good \\
\hline 14 & MKNZ & 3.88 & Good & 3.88 & Good \\
\hline 15 & MSP & 3.38 & Good & 3.38 & Good \\
\hline 16 & MWH & 3.12 & Good & 3.38 & Good \\
\hline 17 & MZE & 3.62 & Good & 3.12 & Good \\
\hline 18 & MZH & 3.62 & Good & 3.62 & Good \\
\hline 19 & MMP & 3.38 & Good & 3.88 & Good \\
\hline 20 & M & 3.88 & Good & 3.62 & Good \\
\hline 21. & MH & 3.75 & Good & 3.88 & Good \\
\hline 22. & MR & 3.12 & Good & 3.88 & Good \\
\hline 23. & NN & 3.62 & Good & 3.38 & Good \\
\hline 24. & NH & 3.62 & Good & 3.88 & Good \\
\hline 25. & NFH & 3.38 & Good & 3.88 & Good \\
\hline 26. & NU & 3.38 & Good & 3.38 & Good \\
\hline 27. & NNA & 3.88 & Good & 3.12 & Good \\
\hline 28. & NH & 3.38 & Good & 3.75 & Good \\
\hline 29. & NSB & 3.62 & Good & 3.88 & Good \\
\hline 30. & RS & 3.75 & Good & 3.88 & Good \\
\hline 31. & SD & & & & \\
\hline 32. & SR & & Good & 3.62 & Good \\
\hline & & MN & \\
\hline
\end{tabular}

Categories:

$4=$ Very good

$2-<3=$ Less good

$3-<4=$ Good

$1-<2=$ Not good

Based on Table-9 social attitudes to work together on all students are good, while at the attitude expressed the opinion of all students also been good.

(Adapted from Nur, 2013) [5]

Students Response Field Test

The response of students in the field testing of the modules can be seen in Table-10.

Table-10: Response of students to the modules on the Field Test

\begin{tabular}{|l|l|l|l|l|}
\hline Nr. & Statement & $\begin{array}{l}\text { The Nnumber of } \\
\text { Students }\end{array}$ & Category \\
\hline 1 & I am very pleased to learn the lab & 31 & 96.88 & Very good \\
\hline 2 & I can understand very well the activities in the module & 28 & 87.50 & Very good \\
\hline 3 & $\begin{array}{l}\text { I came to understand all the material in the modules dealing } \\
\text { with everyday life }\end{array}$ & 25 & 78.12 & Good \\
\hline 4 & I could design an experiment & 28 & 87.50 & Very good \\
\hline 5 & I've been able to process the data after performing experiments & 27 & 84.38 & Good \\
\hline
\end{tabular}

Category: very good (85.01 to $100.00 \%)$, Good (70.01 to 85.00\%), less good (50.01 to $70.00 \%)$, and not good (10.00- 50, 00\%) 
Based on the results of the student's response to the module on field tests above show that the module is acceptable or has been good.

Effectiveness or effective is a condition which implies the occurrence of the desired effect or results in action. The effectiveness of the modules obtained from the learner's cognitive learning, critical thinking skills, attitude, character, social attitudes, and responses of learners. The school sets for class VIII KKM science subjects was 70 and the limit of $80 \%$ classical completeness.

From the data in Table 4.9 learn the results obtained from the data on the subject of six modules in the classical declared complete because it exceeds the value of classical completeness $80 \%$, but some students have not completed because the value is below the value of 70. KKM classical completeness Module 1 by $90,6 \%$, amounting to $96.9 \%$ module 2 , module 3 by $93.8 \%$, amounting to $93.8 \%$ module 4,5 modules of $90.6 \%$, and amounted to $93.8 \%$ module 6 .

Critical thinking skills from the data in Table-7 through the experimental result that critical thinking skills are good. This is supported by previous studies [6]. Critical thinking skills into becoming one indicator of the effectiveness of the module development results. Critical thinking skills students include formulating the problem (inference), make a hypothesis (inference), collect data (interpretation), analyze the data (explanation), and make conclusions (evaluation). So also with previous research Wahyuni [7] reported that the IPA developed practical guidance already eligible for use in teaching in junior and can enhance students' critical thinking skills. Beck [8] argues that learning using the experimental method can enhance innovative teaching methods that can be applied by teachers. The experimental activities can reflect the students' critical thinking skills. According to Bozdogan [9]. The basic principle is reflected in the activities of experimental science. Meanwhile, according to Chabalengula [10], through experiments, students gain experience to hone their science process skills that can later be put into practice in the learning of science. The scarcity of students experimenting to make the critical thinking skills of students is still low. Scriven and Paul, According to Riggs and Hellyer, 2014 [11] no link between the issues and the development of critical thinking. One challenge is the awareness of the role of a real thinker thinking in life and relation with the problems of the day-to-day.

From the data characteristic attitude of learners already shows the attitude diligent and cautious all learners are good. Data from social attitudes of students have demonstrated good cooperation with the attitude, while also a good attitude argues. According to Welch \& Douglas [12], learners will learn to be humble, honest and open thinking in accepting the development of science. Grown scientific attitude of students is one of the indicators that show a positive attitude toward science.

Based on data from Table 10 states that the response of learners towards learning modules developed very positive and could be applied in other classes that supported previous research Dewi et al., [13] concluded that the response data to the module learners developed positively, this means that the students are interested in, understand, and easier when learning to use the modules developed,

Based on these discussions can be concluded that the learning module developed declared effective and can be used or applied to learn in the classroom MTs Muhammadiyah 3 Al-Furqan Banjarmasin. To determine the effectiveness of this development module in other schools need to be tested again in another school.

\section{CONCLUSION}

The results showed a natural science module for grade VIII development results categorized is effective. Categorized based on cognitive learning is good, good critical thinking skills category, categorized character good attitude, the attitude of a good social category, and the students' response has been good.

\section{REFERENCES}

1. OECD Programme for International Student Assessment. (2015). PISA 2015 Released Field Trial Item Kognitif. Doc: CY6_TST_PISA 2015FT Released Cognitive Items.

2. Filsaime, D. K. (2008). Menguak Rahasia Berpikir Kritis dan Kreatif. Jakarta: Prestasi Pustakaraya.

3. Plomp, T., \& Nieveen, N. (2007, November). An introduction to educational design research. In Proceedings of the seminar conducted at the East China Normal University, Shanghai (PR China) (pp. 23-26).

4. Tessmer, M. (1998). Planning and Conducting Formative Evaluation. London: Cogan Page.

5. Nur, M. (2013). Pendidikan dan Latihan Pembelajaran Inovatif dan Pengembangan Perangkat pembelajaran Bermuatan Keterampilan Berpikir dan Perilaku Berkarakter. Kerjasama Program Studi Magister Pendidikan Biologi PPs Unlam dengan Pusat Sains dan Matematika Sekolah (PSMS) UNESA.

6. Kurniawati, W., \& Atmojo, E. S. (2015). Pengembangan Lembar Kerja Berbasis Inkuiri Terintegrasi Kelompok Mata Pelajaran Perekat Bangsa untuk Menumbuhkan Kemampuan Berpikir dan Karakter Ilmiah Siswa. Jurnal Elementary School (online), 2(1): 47-53. (http://upy.ac.id/ ojs/index.php/elementaryschool/ article/view File/54/46), access at July 25, 2018.

7. Wahyuni, S. (2015). Pengembangan Petunjuk Praktikum IPA Untuk Meningkatkan Kemampuan 
Berpikir Kritis Siswa SMP. Jurnal Pengajaran MIPA, 20(2): 196-203.

8. Beck, K., Witteck, T., \& Eilks, I. (2010). Open Experimentation on Phenomena of Chemical Reactions via the Learning Company Approach in Early Secondary Chemistry Education. Eurasia Journal of Mathematics, Science, \& Technology Education. 6(3): 163-171.

9. Bozdogan, A. E., \& Yalcin, N. (2009). Determining the Influence of a Science Exhibition Center Training Program on Elementary Pupils Interest and Achievement in Science. Eurasia Journal of Mathematics, Science, \& Technology Education, 5(1): 27-34.

10. Chabalengula, V. M., Mumba, F., \& Mbewe, S. (2012). How Pre-Service Teachers Understand and Perform Science Process Skills. Eurasia
Journal of Mathematics, Science, \& Technology Education, 8(3): 167-176.

11. Riggs, L. W., \& Hellyer R. S. 2014. Development and motivation In/For critical thinking. Journal of College Teaching \& Learning. (Online), 11(1): 1. Retrieved from http://search.proquest.com/docview/1477975513? accountid=13771.

12. Welch, A., \& Huffman, D. (2011). The effect of robotics competitions on high school students' attitudes toward science. School Science and Mathematics, 111(8), 416-424.

13. Dewi, A. P., \& Prayitno, B. A. (2014). Pengembangan Modul IPA Terpadu Untuk SMP/MTs Berbasis Eksperimen Pada Tema Fotosintesis Untuk Memberdayakan Keterampilan Proses Sains. Inkuiri, 3(3): 30-40. 